\title{
Prevalence and Associated Factors of Canine Visceral Leishmaniasis in an Endemic Area of Mato Grosso, Brazil
}

\author{
Mahyumi Fujimori', Arleana do Bom Parto Ferreira de Almeida', Álvaro Felipe Lima Ruy Dias', \\ Juliana Yuki Rodrigues', Luciano Nakazato', Maria de Fátima Madeira² \& Valéria Régia Franco Sousa'
}

\begin{abstract}
Background: Canine visceral leishmaniasis is a chronic and severe disease of great interest to global public health. In Brazil, the main species causing visceral leishmaniasis is Leishmania chagasi [syn. Leishmania infantum], which is transmitted by sandflies of the species Lutzomyia longipalpis and Lu. cruzi. This study aimed to determine the risk factors and prevalence of visceral leishmaniasis in dogs residing in endemic areas of the municipality of Várzea Grande, Mato Grosso. Material, Methods \& Results: The study was conducted in the Várzea Grande neighbourhoods Jardim Eldorado, Parque Sabiá and São Mateus, which are located in the Brazilian Cerrado region and are endemic for visceral leishmaniasis. The Várzea Grande is a mostly commercial and industrial municipality and relies on subsistence farming. To describe the general characteristics of the dog population and housing environment, an interview was carried out with the dog owners in each household. This interview addressed local demographics and the identification of dogs to establish epidemiological aspects of canine illness and risk factors for infection. The dogs were examined and physically restrained for blood collection by jugular venipuncture. For serological testing, a commercial enzyme-linked immunosorbent assay (ELISA) was used. A Chi-square test or Fisher's exact test was used to identify associations between independent variables and the seroprevalence of dogs with anti-Leishmania antibodies. It were collected blood from 521 animals, including 160 belonging to Jardim Eldorado, 129 to Parque Sabiá and 232 to São Mateus. Of these animals, 120 were reactive by ELISA, with a prevalence of $23.0 \%$. There was no statistically significant difference $(P>0.05)$ according to gender, age, racial definition, origin, time with family, presence of ectoparasites, or the presence of people with skin wounds at home or on other pets. The major risk factor for canine infection was fur length; dogs with short fur were 2.2 times more likely to be infected than dogs with long fur.

Discussion: The prevalence of canine leishmaniasis in endemic areas was found to be similar to studies in Cuiaba, a city in Várzea Grande, which also included neighbourhoods endemic for visceral leishmaniasis as study areas. Other studies have shown prevalence rates that differ from those found in this study. This difference may either be because the neighbourhoods in this study had already experienced outbreaks of the disease or because serum samples were cross-reactive with other trypanosomatids. While infection was more readily detected in dogs with clinical signs, asymptomatic dogs with anti-Leishmania antibodies were found in greater numbers, which is consistent with the literature. Hair length was the only factor associated with canine leishmaniasis in this study; short-haired animals were most at risk of contracting the disease because they had more skin exposure to sandflies during blood feeding. In conclusion, endemic districts of Várzea Grande had high prevalence rates of canine visceral leishmaniasis, and a short length coat was associated with infection.
\end{abstract}

Keywords: Leishmania chagasi, epidemiology, dog, cerrado. 


\section{INTRODUCTION}

Visceral leishmaniasis (VL) is a neglected disease of great importance to global public health. In Brazil, the principal species that causes VL is Leishmania chagasi [syn. Leishmania infantum], and Lutzomyia longipalpis and Lu. cruzi are the vectors [17].

Many mammalian species are naturally infected by L. chagasi, but dogs are the most important reservoir of this parasite in urban areas due to their proximity to human beings [16,24]. Dogs represent the major source of infection for the vector because dogs can have intense skin parasitism independent of their clinical presentation [7]. Several factors, including the presence of dogs in the home, higher rates of dog seropositivity in nearby areas, lower socioeconomic status and highly vegetated areas [4], are associated with human infections.

In Brazil, the techniques recommended by the Ministry of Health for the assessment of sera are the Dual Path Platform (DPP) and the enzymelinked immunosorbent assay (ELISA) [12]. This aspect is important for the elimination of false-positive dogs and the maintenance of non-serum-reactive infected dogs in endemic areas, which facilitates the diagnosis, control and prevention of visceral leishmaniasis.

The continual identification of human and canine cases since 1998 [18] and the occurrence of phlebotominae (Lu. longipalpis) in the city of Várzea Grande, mainly in Jardim Eldorado, São Matheus and Parque Sabiá [21] neighbourhoods, motivated us to investigate the factors associated with $L$. chagasi infections in dogs by serology.

\section{MATERIALS AND METHODS}

\section{Study area and canine sampling}

Transversal study was conducted in the neighbourhoods of Jardim Eldorado, Parque Sabiá and São Mateus in the municipality of Várzea Grande [S 1557'55"; W 5458'06"; (Figure 1); and altitude $367 \mathrm{~m}]$. This area is located in the Brazilian Cerrado region. The climate is humid, tropical and has an average annual temperature of $17^{\circ} \mathrm{C}$ to $32^{\circ} \mathrm{C}$. The estimated population in 2013 was 262,880 inhabitants [13].

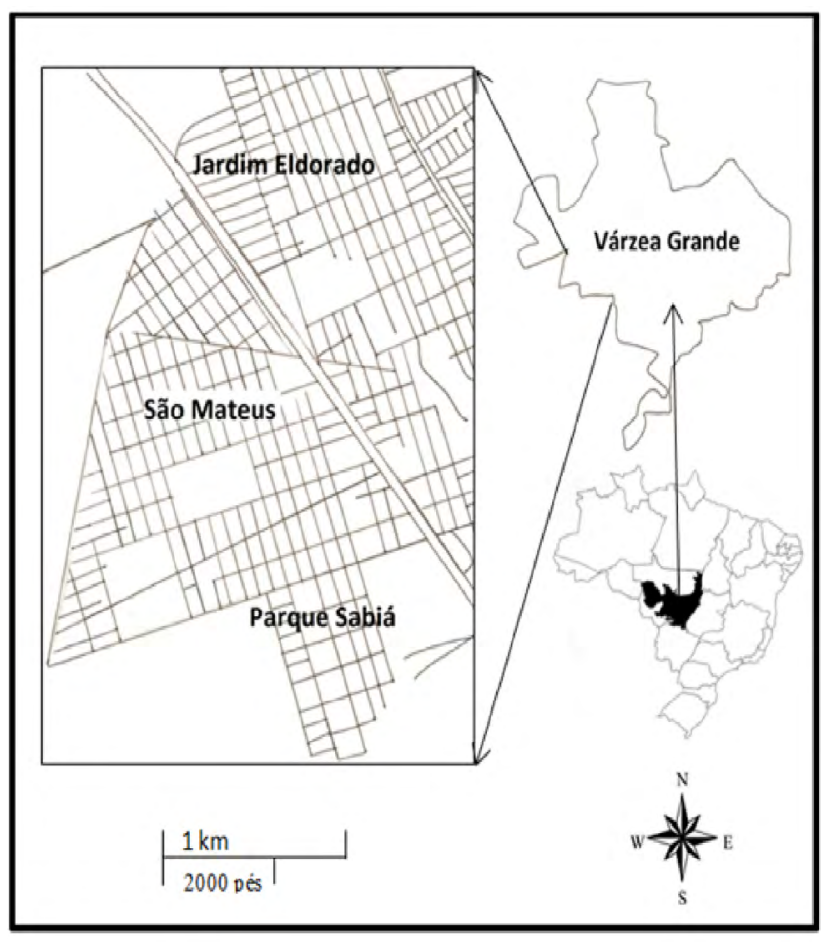

Figure 1. Map of Brazil highlighting the Cerrado region of Mato Grosso and the city of Várzea Grande, showing the neighbourhoods of Jardim Eldorado, Parque Sabiá and São Matheus.

This study was conducted on the canine population, and the sampling was defined by the Epi Info 3.3.2 program (Center for Disease Control and Prevention [CDC], Atlanta, GA, USA) considering a CVL prevalence of $8.4 \%$ [21] with $95 \%$ confidence intervals and an acceptable error of $2 \%$. The populational proportion was one dog for every seven human inhabitants $(1: 7)[1,22]$. The minimum sample size needed was estimated at 498 animals, including dogs of both sexes and aged 6 months or more. The survey was conducted through home visits considering one residence out of every five.

\section{Epidemiological questionnaire, clinical exam and sample collection}

To establish epidemiological aspects, the questionnaire probed the following: local demographics (distance of the domicile from forests, unused land, rivers, or dams; presence of others animals: chicken, pigs, equines, cats, or dogs); characteristics of the animals (sex, age, and breed); whether the animals had access to the street; and the presence of dogs or people with leishmaniasis in the neighbourhood. 
Whole blood ( $5 \mathrm{~mL}$ ) was collected by jugular venipuncture. After centrifugation, the serum samples were put into microtubes and stored at $-20^{\circ} \mathrm{C}$ until the serological test could be performed.

\section{Diagnostic Methods}

The enzyme-linked immunosorbent assay (ELISA) was performed using a commercial kit produced by Bio-Manguinhos ${ }^{\circledR}$ (FIOCRUZ, Rio de Janeiro, Brazil) in accordance with the manufacturer's recommendations.

\section{Statistical Analysis}

The prevalence values were calculated with $95 \%$ confidence intervals, and a Chi-squared test $\left(\chi^{2}\right)$ or Fisher's exact test was used to test the associations between independent variables and the seroprevalence of anti-Leishmania antibodies in dogs using the EpiInfo 3.3.2 program (CDC, Atlanta, USA). The variables with a $P \leq 0.20$ in the univariate analysis were selected for the multivariate analysis. The $\chi^{2}$ goodness-of-fit test was performed using the Hosmer and Lemeshow statistic, and $P \leq 0.05$ was considered significant.

Table 1. Statistical variables related to the risk of Leishmania chagasi infection in the city of Várzea Grande, Mato Grosso, Brazil.

\begin{tabular}{|c|c|c|c|c|c|c|}
\hline \multirow{2}{*}{ Variable } & \multicolumn{2}{|c|}{ Dogs } & \multicolumn{2}{|c|}{ Univariate Analysis } & \multicolumn{2}{|c|}{ Multivariate Analysis } \\
\hline & Total & Positive (\%) & $P$ & OR (CI95\%) & $P$ & OR (CI95\%) \\
\hline \multicolumn{7}{|l|}{ Gender } \\
\hline Male & 267 & $60(50)$ & 0.75 & 0.94 & --- & --- \\
\hline Female & 254 & $60(50)$ & & $(0.61-1.44)$ & & \\
\hline \multicolumn{7}{|l|}{ Breed } \\
\hline Mixed & 468 & $112(93.3)$ & 0.2 & 1.77 & 0.12 & --- \\
\hline Pure & 53 & $8(6.7)$ & & $(0.77-4.20)$ & & \\
\hline \multicolumn{7}{|l|}{ Fur length } \\
\hline Short & 467 & $113(94.2)$ & 0.04 & 2.0 & 0.05 & 2.24 \\
\hline Long & 54 & $7(5.8)$ & & $(1.0-6.4)$ & & $(0.98-5.12)$ \\
\hline \multicolumn{7}{|l|}{ Origin of the dog } \\
\hline Várzea Grande & 440 & $106(88.3)$ & 0.19 & 1.52 & 0.17 & --- \\
\hline Others & 81 & $14(11.7)$ & & $(0.79-2.95)$ & & \\
\hline \multicolumn{7}{|l|}{ Dog Habitat } \\
\hline Outdoor & 503 & $118(98.3)$ & 0.17 & 2.45 & 0.23 & --- \\
\hline Indoor & 18 & $2(1.7)$ & & $(0.53-10.81)$ & & \\
\hline \multicolumn{7}{|l|}{ Vegetation } \\
\hline Yes & 451 & $104(86.3)$ & 00 & 1.01 & & \\
\hline No & 70 & $14(13.7)$ & 0.9 & $(0.54-1.93)$ & -- & --- \\
\hline \multicolumn{7}{|c|}{ Access to the street } \\
\hline Yes & 179 & $78(65)$ & 095 & 1.04 & --- & --- \\
\hline No & 342 & $42(35)$ & 0.93 & $(0.66-1.63)$ & -- & -- \\
\hline \multicolumn{7}{|l|}{ Domestic animals } \\
\hline Yes & 437 & $95(79.2)$ & 014 & 0.66 & --- & \\
\hline No & 84 & $25(20.8)$ & 0.14 & $(0.38-1.14)$ & -- & --- \\
\hline \multicolumn{7}{|l|}{ Trees in the yard } \\
\hline Yes & 268 & $65(54.2)$ & 0.56 & 1.15 & --- & --- \\
\hline No & 253 & $55(45.8)$ & 0.50 & $(0.75-1.77)$ & -- & --- \\
\hline \multicolumn{7}{|l|}{ Livestock } \\
\hline Yes & 137 & $23(19.2)$ & 003 & 1.48 & 003 & 0.57 \\
\hline No & 384 & $97(80.8)$ & 0.05 & $(1.02-2.27)$ & 0.05 & $(0.34-0.96)$ \\
\hline \multicolumn{7}{|c|}{ LVH neighborhood } \\
\hline Yes & 42 & $09(7.5)$ & 094 & 1.11 & --- & --- \\
\hline No & 479 & $111(92.5)$ & 0.94 & $(0.49-2.57)$ & -- & --- \\
\hline \multicolumn{7}{|l|}{ LVC neighborhood } \\
\hline Yes & 69 & $12(10)$ & 079 & 1.49 & & \\
\hline No & 452 & $108(90)$ & 0.29 & $(0.74-3.05)$ & -- & --- \\
\hline \multicolumn{7}{|l|}{ Vector } \\
\hline Yes & 56 & 11(9.2) & 0.63 & 1.25 & --- & --- \\
\hline No & 465 & $109(90.8)$ & & $(0.60-2.67)$ & -- & --- \\
\hline
\end{tabular}




\section{RESULTS}

A total of 521 dogs were examined: 160 were from Jardim Eldorado, 129 were from Parque Sabiá, and 232 were from the São Matheus neighbourhood. Of these animals, 120 were positive by ELISA, yielding a prevalence of $23.0 \%$.

Of the seropositive dogs, 40 (17.2\%) did not present any clinical signs, and $80(27.8 \%)$ were symptomatic. The symptomatic dogs had a 1.8 (1.2 - 2.9)-fold greater chance of their infection being detected than the asymptomatic ones. The most common clinical signs were dermopathies, such as ulcers on the tips of the ears, thinning of the hair, hyperkeratosis and peeling, followed by splenomegaly, lymphadenopathy, onychogryphosis, progressive weight loss and ophthalmopathy.

According to the data, there was no significant difference $(P>0.05)$ regarding sex, age, breed, time with the family, presence of ectoparasites, presence of persons with cutaneous wounds in the residence or the company of other animals.

The determining risk factor for canine infection was fur length. Dogs with short fur had a 2.2 (0.9 - 5.1)fold greater chance of infection than dogs with long fur. However, the existence of unused land or forests near dwellings was not a risk factor for leishmaniasis in the dogs of the studied locality (Table 1).

\section{DISCUSSION}

The seroprevalence of the disease was $23.0 \%$, which is similar to the results obtained in the municipality of Cuiabá [2], which adjoins Várzea Grande at the endemic suburbs. However, 3.4\% prevalence was found in Cuiabá in areas with low awareness of the canine disease [15]. Other localities, such as Juiz de Fora, Minas Gerais, presented with $3.8 \%$ prevalence [5]. The rural area of Minas Gerais had a prevalence of $19.9 \%$ [10]. Araguaína, Tocantins presented with a prevalence of $51.35 \%$ [20]. This difference may be associated with the endemicity of the area [19] and the technique used. The study area continues to present new cases, despite the recommended control measures, such as canine sacrifice [6].

In CVL epidemiology, asymptomatic dogs are very important because they maintain and carry the parasite [15]. These dogs are also found in greater numbers in endemic areas [2,11], as observed in this study, even though the infections were detected more easily in the dogs that presented with clinical signs.
No significant difference was found regarding sex, age or breed [8]. Thus, regardless of any of the characteristics cited, the animals were subject to infection by the parasite provided that the vector existed. Neither the origin nor the travel habits of the dogs presented any significant differences in this study, although this result had previously been demonstrated [14].

Fur length was a predictive factor for the incidence of leishmaniasis, similar to a previous report [3,9]. Thus, animals with a short coat have a greater risk than dogs with long hair because their skin is more exposed to phlebotomines during bloodmeals. The presence of livestock (swine or birds) in the domicile was not a risk factor for the disease, even though these animals have been considered a food source for the vector. In addition, these animal species sometimes accumulate large quantities of organic matter, which creates an ideal substrate for insect reproduction [3].

Although these neighbourhoods are adjacent to areas surrounding the savannah that may favour the vector's life cycle [23], the presence of forests and unused land near the dwellings was not a risk factor. This observation suggests a possible adaptation of the vector to anthropic environments [2].

\section{CONCLUSIONS}

Despite prevention and control measures imposed in this endemic area, there was still a high prevalence of dogs with $L$. chagasi infections in this study, and the main associated factor for canine infection was short fur length.

Funding. This research was supported by Conselho Nacional de Desenvolvimento Científico e Tecnológico (CNPq) grant number 480402/2011-6 and Fundação de Amparo à Pesquisa do Estado de Mato Grosso (FAPEMAT) grant number 332387/2012.

Acknowledgements. To FAPEMAT, CNPq, Coordenação de Aperfeiçoamento de Pessoal de Nível Superior (CAPES), Comissão Nacional de Residência Multiprofissional em Saúde (CNRMS) and Programa Institucional de Bolsas de Iniciação Científica (PIBIC) for scholarship.

Ethical approval. This study was conducted in accordance with the ethical principles approved by the Ethics Committee for Animal Research of the Federal University of Mato Grosso [Comitê de Ética no Uso de Animais-Universidade Federal De Mato Grosso (CEUA-UFMT)] under protocol number 23108.018081/12-0. The dog owners were informed of the research objectives and were required to sign an informed consent form before sample and data collection.

Declaration of interest. The authors declare that there is no conflict of interest. The authors alone are responsible for the content and writing of the paper. 


\section{REFERENCES}

1 Almeida A.B.P.F., Faria R.P., Pimentel M.F.A., Dahroug M.A.A., Turbino N.C.M.R. \& Sousa V.R.F. 2009. Inquérito soroepidemiológico de leishmaniose canina em áreas endêmicas de Cuiabá, Estado de Mato Grosso. Revista da Sociedade Brasileira de Medicina Tropical. 42(2): 156-159.

2 Almeida A.B.P.F., Sousa V.R.F., Cruz F.A.C.S., Dahroug M.A.A., Figueiredo F.B. \& Madeira M.F. 2012. Canine visceral leishmaniasis: seroprevalence and risk factors in Cuiabá, Mato Grosso, Brazil. Revista Brasileira de Parasitologia Veterinária. 21(4): 359-365.

3 Barboza D.C.P.M., Gomes Neto C.M.B., Leal D.C., Bittencourt D.V.V., Carneiro A.J.B., Souza B.M.P.S. Oliveira L.S. Julião F.S. Souza V.M.M. \& Franke C.R. 2006. Estudo de coorte em áreas de risco para leishmaniose visceral canina, em municípios da Região Metropolitana de Salvador, Bahia, Brasil. Revista Brasileira de Saúde e Produção Animal. 7(2): 152-163.

4 Belo V.S., Werneck G.L., Barbosa D.S., Simões T.C., Nascimento B.W.L., Silva E.S. \& Struchiner C.J. 2013. Factors Associated with Visceral Leishmaniasis in the Americas: A Systematic Review and Meta-Analysis. PLoS Neglected Tropical Diseases. 7(4): e2182.

5 Castro-Júnior J.G., Freire M.L., Campos S.P.S., Scopel K.K.G., Porrozzi R., Da Silva E.D., Colombo F.A., da Silveira R.C., Marques M.J. \& Coimbra E.S. 2014. Evidence of Leishmania (Leishmania) infantum infection in dogs from Juiz de Fora, Minas Gerais State, Brazil, based on Immunochromatographic Dual-Path Platform (DPP $\left.{ }^{\circledR}\right)$ and PCR assays. Revista do Instituto de Medicina Tropical de São Paulo. 56(3): 225-229.

6 Costa D.N.C.C., Codeço C.T., Silva M.A. \& Werneck G.L. 2013. Culling Dogs in Scenarios of Imperfect Control: Realistic Impact on the Prevalence of Canine Visceral Leishmaniasis. PLoS Neglected Tropical Diseases. 7(8): e2355.

7 Coura-Vital W., Ker H.G., Roatt B.M., Soares R.D.O.A., Leal G.G.A., Moreira N.D., Oliveira L.A., Menezes Machado E.M., Morais M.H., Correâ-Oliveria R., Carneiro M. \& Reis A.B. 2014. Evaluation of Change in Canine Diagnosis Protocol Adopted by the Visceral Leishmaniasis Control Program in Brazil and a New Proposal for Diagnosis. PLoS One. 9(3): e91009.

8 Coura-Vital W., Reis A.B., Fausto M.A., Leal G.G.A., Marques M.J., Veloso V.M. \& Carneiro M. 2013. Risk Factors for Seroconversion by Leishmania infantum in a Cohort of Dogs from an Endemic Area of Brazil. Plos One. 8(8): e71833.

9 Coura-Vital W., Reis A.B., Reis L.E., Braga S.L., Roatt B.M., Aguiar-Soares R.D., Marques M.J., Veloso V.M. \& Carneiro M. 2013. Canine visceral leishmaniasis: incidence and risk factors for infection in a cohort study in Brazil. Veterinary Parasitology. 197(3-4): 411-417.

10 Curi N.H.A., Paschoal A.M.O., Massara R.L., Marcelino A.P., Ribeiro A.A., Passamani M. Demétrio G.R. \& Chiarello A.G. 2014. Factors Associated with the Seroprevalence of Leishmaniasis in dogs living around Atlantic Forest Fragments. PLoS One. 9(8): e104003.

11 Dantas-Torres F. 2006. Situação atual da epidemiologia da leishmaniose visceral em Pernambuco. Revista de Saúde Pública. 40(3): 537-541.

12 Grimaldi Júnior G., Teva A., Ferreira A.L., Santos C.B., Pinto I.S., Azevedo C.T \& Falqueto A. 2012. Evaluation of a novel chromatographic immunoassay based on Dual-Path Platform technology (DPP ${ }^{\circledR}$ CVL rapid test) for the serodiagnosis of canine visceral leishmaniasis. Transactions of the Royal Society of Tropical Medicine Hygiene. 106(1): 54-59.

13 Instituto Brasileiro de Geografia e Estatística (IBGE). 2013. Cidades. Disponível em: http://www.ibge.gov.br/ cidadesat/default.php. [Accessed online November 2013].

14 Julião F.S., Souza B.M.P.S., Freitas D.S., Oliveira L.S., Laranjeira D.F., Dias-Lima A.G., Souza V.M.M., BarrouinMelo S.M., Moreira Jr. E.D., Paule B.J.A. \& Franke C.R. 2007. Investigação de áreas de risco como metodologia complementar ao controle da leishmaniose visceral canina. Pesquisa Veterinária Brasileira. 27(8): 319-324.

15 Laurenti M.D., Rossi C.N., Matta R.V.L., Tomokane T.Y., Corbett C.E.P., Secundino N.F.C., Pimenta P.F. \& Marcondes M. 2013. Asymptomatic dogs are highly competent to transmit Leishmania (Leishmania) infantum chagasi to the natural vector. Veterinary Parasitology. 196(3-4): 296-300.

16 Marzochi M.C.A., Fagundes A., Andrade M.V., Souza M.B., Madeira M.F., Mouta-Confor E., Schubach A.O. \& Marzochi K.B. 2009. Visceral leishmaniasis in Rio de Janeiro, Brazil: eco-epidemiological aspects and control. Revista da Sociedade Brasileira de Medicina Tropical. 42(5): 570-580. 
17 Ministério da Saúde (MS). 2006. Secretaria De Vigilância Em Saúde. Departamento De Vigilância Epidemiológica. Manual de Vigilância e Controle da Leishmaniose Visceral. Brasília: Ministério da Saúde, 120 p.

18 Mestre G.L.C. \& Fontes C.J.F. 2007. A expansão da epidemia de leishmaniose visceral no Estado de Mato Grosso, 1998-2005. Revista da Sociedade Brasileira de Medicina Tropical. 40(1): 42-48.

19 Missawa N.A. \& Borba J.F. 2009. Leishmaniose visceral no município de Várzea Grande, estado de Mato Grosso, no período de 1998 a 2007. Revista da Sociedade Brasileira de Medicina Tropical. 42(5): 496-502.

20 Morais A.N., Sousa M.G., Meireles L.R., Kesper Jr. N. \& Umezawa E.S. 2013. Canine visceral leishmaniasis and Chagas disease among dogs in Araguaína, Tocantins. Revista Brasileira de Parasitologia Veterinária. 22(2): 225-229.

21 Ribeiro A.L.M \& Missawa N.A. 2002. Spatial distribution of phlebotomine species in the state of Mato Grosso, Brazil, in the period of 1996 to 2001. Entomología y Vectores. 9: 33-34.

22 Savani E.S.M.M., Schimonsky B.V., Camargo M.C.G.O. \& D’áuria S.R.N. 2003. Vigilância de leishmaniose visceral americana em cães de área não endêmica, São Paulo. Revista de Saúde Pública. 37(2): 260-262.

23 Silva E.S., Gontijo C.M.F. \& Melo N.M. 2005. Contribution of molecular technique to the epidemiology of neotropical Leishmania species. Trends in Parasitology. 21(12): 550-552.

24 Teixeira Neto R.G., Giunchetti R.C., Carneiro C.M., Vitor R.W.D.A., Coura-Vital W., Quaresma P.F., Ker H.G., Melo L.A., Gontijo C.M. \& Reis A.B. 2010. Relationship of Leishmania-specific IgG levels and IgG avidity with parasite density and clinical signs in canine leishmaniasis. Veterinary Parasitology. 169(3-4): 248-257. 